\title{
Familial advanced sleep-phase syndrome
}

INSERM

\section{Source}

INSERM. (1999). Orphanet: an online rare disease and orphan drug data base. Familial advanced sleep-phase syndrome. ORPHA:164736

Familial advanced sleep-phase syndrome (FASPS) is a very rare circadian rhythm sleep disorder characterized by very early sleep onset and offset possibly resulting in emotional and physical disruptions. 